Andrej GULIČ

Sergeja PRAPER

\title{
Vključevanje prostorskega in okoljskega vidika $v$ regionalne razvojne programe v programskem obdobju 2007-2013 ${ }^{[1]}$
}

\begin{abstract}
$\checkmark$ prispevku analiziramo vključenost prostorskega in okoljskega vidika $v$ dokumente razvojnega načrtovanja, regionalne strukturne politike ter prostorskega in okoljskega načrtovanja na državni, regionalni in lokalni ravni. Predlagamo usmeritve za izpopolnitev sistema razvojnega načrtovanja ter za vključevanje prostorskega in okoljskega vidika $v$ pripravo nove generacije regionalnih razvojnih programov. Predstavljamo tudi možnosti za povezovanje priprave regionalnih razvojnih programov in regionalnih zasnov prostorskega razvoja.
\end{abstract}

\begin{abstract}
The article presents analyses of integration of spatial and environmental aspects in documents concerning development planning, regional structural policy and physical and environmental planning on the national, regional and local level. These are followed with guidelines for amending the system of development planning and integration of physical and environmental aspects into the new generation of regional development programmes. Possibilities for linking regional development programmes and regional concepts of spatial development are also presented.
\end{abstract}

Prostorsko načrtovanje Razvojno načrtovanje Regionalna strukturna politika

Regionalna zasnova prostorskega razvoja Regionalni razvojni program

Varstvo okolja

Development planning Environmental protection Physical planning

Regional concept of spatial development Regional development concept

Regional structural policy

\section{Uvodne ugotovitve}

Regionalni razvojni programi za programsko obdobje 2001-2006 (v nadaljevanju RRP) so bili pripravljeni v skladu z Navodilom o minimalni obvezni vsebini in metodologiji priprave ter načinu spremljanja in vrednotenja regionalnega razvojnega programa [2]. (v nadaljevanju Navodilo) ter $\mathrm{z}$ veljavnim Zakonom o spodbujanju skladnega regionalnega razvoja [3] (v nadaljevanju Zakon o regionalnem razvoju). Navodilo med drugim podaja metodični okvir za poenotenje vsebine RRP in usmeritve, ki naj bi zagotovile preglednost postopka priprave, spremljanja, vrednotenja in nadzora.

Pregled vsebin RRP, ki smo ga opravili pri izvajanju analitičnih faz projekta Spremljanje regionalnega razvoja[4], je pokazal, da so pripravljalci sledili Navodilu in pripravili dokumente $\mathrm{z}$ dokaj uravnoteženo razporeditvijo gospodarskih, socialnih, prostorskih in okoljskih vsebin po razvojnih prioritetah, programih in podprogramih. Kljub metodičnim razlikam so nastali dokumenti, za katere lahko na splošno sklenemo, da imajo vseobsežen in celovit značaj. Naj ob tem navedemo, da za strateške, predvsem pa izvedbene vsebine dokumentov ni bilo izvedeno razvrščanje predlaganih razvojnih usmeritev po pomembnosti, kar pogosto otežuje izvajanje RRP.

RRP, še posebno tisti najbolj zgodnji (RRP Koroške in Savinjske), so nastajali $\mathrm{v}$ času priprave ključnih nacionalnih programskih dokumentov: Strategije gospodarskega razvoja RS, Državnega razvojnega programa RS 2001-2006, Strategije regionalnega razvoja Slovenije in Strategije prostorskega razvoja Slovenije. Vsebine prvih RRP so bile ob sledenju načelu regulacije od spodaj navzgor ena od osnov za pripravo omenjenih državnih razvojnih dokumentov kot tudi nekaterih poznejših RRP.

Pri oceni stanja in predlogih vključevanja prostorskega in okoljskega vidika $\mathrm{v}$ novo generacijo RRP, ki jih podajamo $\mathrm{v}$ nadaljevanju, se osredotočamo predvsem na izkušnje in spoznanja, ki smo jih pridobili v procesu priprave RRP Koroške[5], kjer je Urbanistični inštitut RS bil odgovoren za področji prostorskega in okoljskega vidika razvoja, in priprave regionalnih zasnov prostorskega razvoja koroške [6] in savinjske regije [7] (v nadaljevanju RZPR), kjer je bil izvajalec projektov. 


\section{Izhodišča}

\subsection{Zakonski in razvojno-strateški okvir}

Zakon o regionalnem razvoju in Navodilo ne opredeljujeta natančneje vsebin za področja, ki naj bodo obravnavana v RRP, torej tudi ne za prostorski in okoljski vidik regionalnega razvoja.

Obravnava prostorskega vidika je pri pripravi sedaj veljavnih RRP potekala ob zakonskem okviru na področju urejanja prostora, ki se je navezoval na sistem vseobsežnega družbenega planiranja, ter ob regulacijskem okviru, ki ga je na državni ravni predstavljal Dolgoročni prostorski plan Slovenije s časovnim okvirom od leta 1986 do leta 2000, na lokalni ravni pa občinski prostorski plani.

V letu 2003 je začel veljati novi Zakon o urejanju prostora [8], s katerim so bili uveljavljeni novi cilji ter načela in sistem urejanja prostora. Zakon ureja tudi prostorsko načrtovanje na regionalni ravni, in sicer predvideva pripravo regionalnih zasnov prostorskega razvoja. Poleg tega je bila sprejeta Strategija prostorskega razvoja Slovenije [9] (v nadaljevanju Strategija prostorskega razvoja), ki določa izhodišča in cilje prostorskega razvoja Slovenije, podaja zasnovo prostorskega razvoja s prioritetami in usmeritvami za dosego ciljev ter smernice za razvoj prostorskih sistemov $\mathrm{z}$ usmeritvami za razvoj na regionalni in lokalni ravni.

$\mathrm{Na}$ področju okolja sta bila v obdobju priprave prve generacije RRP veljavna Zakon o varstvu okolja, sprejet leta 1993, ter Nacionalni program varstva okolja $z$ operativnimi programi za nekatera področja, kot npr. ravnanje $z$ odpadki. Za območja širših lokalnih skupnosti je zakon predvidel možnost izdelave programov varstva okolja, način vključevanja vidika varstva okolja v regionalno razvojno načrtovanje pa ni bil opredeljen.
Tudi na področju okolja so nastale spremembe zakonskih in razvojnostrateških osnov: v letu 2004 je bil sprejet nov zakon o varstvu okolja[10], junija 2005 pa še Resolucija o nacionalnem programu varstva okolja z operativnimi programi.[11]

Novi zakon o varstvu okolja glede na prejšnjega na področju regionalnega razvojnega načrtovanja ne prinaša bistvenih sprememb: za širše lokalne samoupravne skupnosti je še vedno predvidena le možnost priprave programa varstva okolja, pri izdelavi RRP pa bi lahko nastala obveznost priprave celovite presoje vplivov na okolje. Resolucija o nacionalnem programu varstva okolja (v nadaljevanju Resolucija) po drugi strani zahteva vključevanje okoljskih vidikov $\mathrm{v}$ vse politike in dejavnosti na državni, regionalni in lokalni ravni. Predvidenih je več orodij, kot npr. upoštevanje okoljskih ciljev pri pripravi dokumentov, redno spremljanje vključevanja ob pomoči kazalcev, uporaba okoljskih meril v programih financiranja, izvajanje celovite presoje vplivov na okolje.

Vidiki varstva okolja so ustrezno vključeni $v$ sistem načrtovanja prostorskega razvoja. Zakon o urejanju prostora vsebuje zahtevo, da je potrebno ob načrtovanju prostora zagotavljati varstvo okolja, ohranjanje narave, trajnostno rabo naravnih dobrin ter varovati druge kakovosti naravnega in bivalnega okolja. Pri pripravi prostorskih aktov naj bi se zahteve varstva okolja vključevale $\mathrm{v}$ urejanje prostora skozi izhodišča, načela, cilje, prostorske usmeritve in pravila za urejanje prostora (Resolucija: 9). Eden od ciljev Strategije prostorskega razvoja se nanaša neposredno na varstvo okolja, okoljevarstvene vsebine pa so upoštevane tudi pri obravnavi posameznih prostorskih sistemov.

\subsection{Vsebinska izhodišča}

\section{Državna raven}

Med RRP so, kar zadeva prostorski in okoljski vidik, razlike v struktur- nem prikazu in vsebini predlaganih razvojnih prioritet, programov in podprogramov. Podobne razlike lahko zasledimo tudi med RRP in Državnim razvojnim programom 2001-2006.[12] Slednji temelji na dokumentu Strategija gospodarskega razvoja Slovenije (v nadaljevanju Strategija gospodarskega razvoja), ki je ključni slovenski izvedbeni dokument dolgoročnega razvojnega načrtovanja. Eno od najpomembnejših izhodišč Strategije gospodarskega razvoja je enakovredno obravnavanje gospodarske, socialne in okoljske razsežnosti blaginje.

Problematika prostorskega razvoja in varstva okolja se ne pojavlja $\mathrm{v}$ naslovu nobene od opredeljenih razvojnih prednostnih nalog Državnega razvojnega programa, ki so: Spodbujanje podjetniškega sektorja in konkurenčnosti; Znanje, razvoj človeških virov in zaposlovanje; Informacijska družba, infrastruktura in kakovost bivanja; Prestrukturiranje kmetijstva in razvoj podeželja; Krepitev skladnega regionalnega razvoja. Pojavlja pa se v programih prednostne razvojne naloge »Informacijska družba, infrastruktura in kakovost bivanja«: Ravnanje $\mathrm{z}$ odpadki; Varstvo voda in upravljanje $z$ vodami; Zapiranje in okoljska sanacija premogovnikov in rudnikov; Gradnja stanovanj; Energetika; Prometna infrastruktura, ter v programih prednostne razvojne naloge Krepitev skladnega regionalnega razvoja: Integralni program razvoja mest in podeželja; Razvoj kulture in ohranjanje naravne in kulturne dediščine kot dejavnik razvojnega zaposlovanja na regionalni ravni; Program razvoja regionalne infrastrukture.

Kljub temu da vključuje številna področja prostorskega razvoja in varstva okolja na manj transparenten in za prostorsko planiranje nekoliko nenavaden način (glej npr. strukturo Strategije prostorskega razvoja), lahko pozitivno ocenimo vlogo Državnega razvojnega programa kot povezovalca prostorskih 
in okoljskih vsebin $\mathrm{v}$ gospodarsko utemeljene prednostne naloge.

Čeprav je bil Državni razvojni program opredeljen kot ključni slovenski izvedbeni dokument dolgoročnega razvojnega načrtovanja, formalno ni bil sprejet in se ne izvaja, njegovo vlogo pa je v praksi prevzel Enotni programski dokument. [13] Prostorski in okoljski vidik $\mathrm{v}$ dokumentu nista celovito obravnavana. Prostorske vsebine so $\mathrm{v}$ okrnjeni obliki prevzete $\mathrm{v}$ prednostnih projektih na področju razvoja prometne infrastrukture v referenčnem okviru za kohezijski sklad za področje prometa za obdobje 2004-2006 [14], okoljske vsebine pa $\mathrm{v}$ referenčnem okviru $\mathrm{za}$ kohezijski sklad za področje okolja za obdobje 2004-2006.[15]

Kot smo že omenili, RRP glede na to, da so bili pripravljeni pred sprejemom Strategije prostorskega razvoja, s tem dokumentom formalno niso usklajeni.

Poseben problem, ki se je pojavil pri obravnavi prostorskega in okoljskega vidika pa tudi drugih vidikov v procesu priprave RRP, zadeva sodelovanje državnih resornih ministrstev. Vključevanje resornih ministrstev $\mathrm{v}$ pripravo temeljnih programskih in izvedbenih dokumentov na državni in regionalni ravni namreč pogosto ni tvorno. Razloge za takšno stanje lahko iščemo v:

- prevladujočem sektorskem načinu načrtovanja in izvajanja razvojnih nalog, ki jih urejajo področna zakonodaja in področni strateški razvojni dokumenti;

- dejstvu, da resorna ministrstva pri strateškem načrtovanju svojih dejavnosti pogosto ne upoštevajo temeljnih programskih in izvedbenih dokumentov na državni (Strategija gospodarskega razvoja, Strategija razvoja Slovenije, Državni razvojni pprogram) in regionalni ravni (RRP, RZPR), saj omenjeni dokumenti za njih niso obvezno plansko izhodišče;
- pretežno inkrementalnem načinu priprave skupnih (nadresorskih) strateških dokumentov, pri katerem se po načelu napredovanja po majhnih korakih in medsebojnega učenja poskuša upoštevati večino tega, kar resorna ministrstva predlagajo za vključitev v dokument;

- umanjkanju teritorializacije sektorskih strateških razvojnih dokumentov na ravni statističnih regij (npr. regionalna strategija razvoja prometnega sistema in infrastrukture, regionalni programi varstva okolja ipd.), ki bi lahko bili smernice za pripravo RRP in RZPR;

- odsotnosti regionalnih državnih izpostav ali vladnih uradov na regionalni ravni, ki bi skrbeli za poenoteno usmerjanje in izvajanje državnih razvojnih politik in ne le za izvajanje upravnih storitev za državljane in pravne osebe, kar danes opravljajo upravne enote;

- prešibki vlogi Sveta za strukturno politiko kot organa vlade, ki je odgovoren za usklajevanje predlogov dokumentov za izvajanje regionalne strukturne politike na državni ravni;

- prešibki vlogi organa na ravni regije, odgovornega za vsebinsko usmerjanje in spremljanje RRP, ki je poleg tega zelo pogosto spreminjal svojo sestavo (od programskega odbora prek regionalnega razvojnega sveta do aktualnega sveta regije, v katerem ni več predstavnikov države, delodajalcev in delojemalcev, temveč le župani občin).

\section{Regionalna raven}

Obravnava prostorskega in okoljskega vidika v RRP za obdobje 2001-2006 je večinoma sledila uveljavljeni delitvi po področjih. Prostorski razvoj se je obravnaval v okviru razvoja sistema poselitve, razvoja gospodarske javne infrastrukture (prometne, energetske, komunalne in informacijsko-komunikacijske) in krajine. Na po- dročju varstva okolja so teme zajemale predvsem problematiko posameznih sestavin okolja - voda, tla, zrak, naravni viri - in področij, ki se urejajo kot javna gospodarska služba občin: ravnanje z odpadki, oskrba z vodo, odvajanje komunalnih odpadnih vod ipd. Ob tem naj omenimo, da se med cilji RRP pogosto pojavlja trajnostni okoljski in prostorski razvoj regij.

Glede na pretežno dolgoročni značaj se programi in projekti na področju prostora in varstva okolja najbolj izrazito na področju načrtovanja in izgradnje območij poselitve, prometne in energetske infrastrukture, manj pa na področju komunalne in informacijsko-komunikacijske infrastrukture - vsebinsko in časovno težje usklajujejo s programi in projekti na področju gospodarskega in socialnega razvoja. Zaradi tega se pojavljajo precejšnja neskladja pri uresničevanju sprejetih programov in projektov ter razumljive težnje in prizadevanja, da se načrtovane vsebine, ki niso bile udejanjene v projektih, prenesejo v novo programsko obdobje.

Zakon o regionalnem razvoju in Zakon o urejanju prostora sta s podzakonskimi akti, predvsem $\mathrm{Na}$ vodilom in Pravilnikom o podrobnejši vsebini, obliki in načinu priprave regionalne zasnove prostorskega razvoja ter vrstah njenih strokovnih podlag [16] (v nadaljevanju Pravilnik), predvidela možnosti za vsebinsko povezovanje RRP in RZPR. Tako Navodilo $\mathrm{v}$ tretjem odstavku 7. člena opredeljuje, da »regionalna razvojna agencija da pobudo za preverjanje in spremembe sestavin prostorskih aktov, ki se nanašajo na področje delovanja RRP«. V Pravilniku je v drugem odstavku 9. člena opredeljeno, da v primeru, ko je »priprava regionalne zasnove vezana na pripravo regionalnega oziroma območnega razvojnega programa, vsebuje program ukrepov za izvajanje regionalne zasnove tudi naloge in ukrepe za zagotavljanje us- 
klajenega izvajanja razvojnega programa in regionalne zasnove ter njihove nosilce .

Kljub temu da sta si razvojno in prostorsko načrtovanje na regionalni ravni $\mathrm{z}$ zakonsko pomočjo sramežljivo podala roke, se pojavljajo resni problemi, ki zaviralno vplivajo na dejansko uresničitev sinergijske povezanosti obeh razvojnih dokumentov. Naj izpostavimo najvidnejše:

- sočasna in usklajena priprava ali sprememba obeh strateških dokumentov $\mathrm{v}$ enakem teritorialnem okviru ni predvidena. Zakon o regionalnem razvoju in Navodilo nalagata obveznost (okrepil A. G.) priprave RRP na ravni statističnih regij, Zakon o urejanju prostora in Pravilnik pa možnost (okrepil A. G.) priprave RZPR na ravni statističnih regij, če se država in občine za to dogovorijo in če se RZPR navezuje na pripravo RRP (praviloma naj bi se pripravljale tako imenovane problemske RZPR za prostorske ureditve državnega ali regionalnega pomena);

- ni navodil ali usmeritev glede medsebojnega povezovanja ali upoštevanja vsebin RRP in RZPR $\mathrm{v}$ procesu priprave enega ali drugega dokumenta;

- različni časovni horizont veljavnosti dokumentov - RRP se pripravlja za srednjeročno obdobje (5-7 let), RZPR pa za dolgoročno obdobje (15-20 let).

Kljub zgoraj omenjenim problemom, ki vplivajo na »oddaljevanje « RRP od RZPR, obstaja tudi dejavnik, ki ju združuje. Gre za ključne razvojne partnerje, ki sodelujejo pri pripravi in izvajanju obeh strateških dokumentov.

Zakon o regionalnem razvoju $\mathrm{v}$ prvem odstavku 10. člena opredeljuje, da se »z RRP ... uskladijo razvojna predvidevanja in naloge države in občin (okrepil A. G.) na področju gospodarskega, socialnega, prostorskega in okoljskega ter kulturnega razvoja v regiji «, v drugem odstav$\mathrm{ku}$ 11. člena pa je navedeno, da »sklep o pripravi RRP sprejmejo sveti občin, vključeni v njegovo pripravo, in organi drugih oseb javnega in zasebnega prava, ki so pripravljene sodelovati pri pripravi $R R P \ll$ (okrepil A. G.).

Pravilnik v prvem odstavku 2. člena opredeljuje, da se »z RZPR načrtujejo zasnove prostorskih ureditev in z njimi prostorsko in funkcionalno povezanih območij, za katere se država in občine dogovorijo (okrepil A. G.), da jih bodo načrtovale skupaj«.

V obeh primerih sta ključna razvojna partnerja država in občine, ki zastopajo državni in lokalni javni interes. Ostalim deležnikom, npr. predstavnikom gospodarstva ali nevladnim organizacijam, pa je formalno dana le obrobna razvojna vloga.

Kljub neprijaznemu zakonskemu okviru so bili npr. na Koroškem in na regionalnem območju Zgornje Savinjske in Šaleške doline v savinjski regiji predstavniki gospodarstva tvorno vključeni v pripravo RRP in RZPR. V obeh primerih je potrebno poudariti aktivno vlogo območnih gospodarskih zbornic.

\section{Lokalna raven}

Pomembno raven, ki jo je potrebno smiselno upoštevati pri pripravi prostorskega in okoljskega vidika RRP, predstavlja subregionalna oz. lokalna raven. Gre za raven, na kateri se udejanjajo razvojni cilji, usmeritve, programi in projekti nadrejenih državnih in regionalnih strateških dokumentov.

Na lokalni ravni oz. na ravni funkcionalno-interesno sklenjenih območij se, kot predvideva Navodilo, lahko pripravijo območni razvojni programi, ki nastanejo na pobudo območnega razvojnega partnerstva ali sveta regije in morajo biti skladni $\mathrm{z}$ RRP. Nekateri so že pripravljeni [17], drugi so v postopku priprave (npr. za zgornjo savinjsko in šaleško regijo). Poleg tega naj bi se na lokalni ravni pripravljali občinski razvojni programi kot osnovni dokument občinske razvojne strategije in po Zakonu o izvrševanju proračuna za leto 2002/03 (Ur. 1. RS, št. 103/01) obvezna sestavina proračuna. Nekaj občinskih razvojnih programov je že pripravljenih [18], nekateri pa so $\mathrm{v}$ postopku priprave.

$\mathrm{V}$ nobenem od primerov, verjetno zaradi sorazmerno majhnega števila pripravljenih dokumentov, ni bila opravljena analiza, ki bi predstavila razvojno-regulacijski pomen za lokalni razvoj in vpliv na njegovo spodbujanje.

Na lokalni ravni se v okviru izvajanja Zakona o urejanju prostora začenjajo pripravljati strategije prostorskega razvoja občin, ki bodo nadomestile veljavne občinske prostorske plane in bodo predstavljale prostorske akte, s katerimi bo potrebno vsebinsko uskladiti občinske razvojne strategije. Zakon o urejanju prostora in Pravilnik predvidevata tudi možnost izdelave RZPR za območje, za katero se pripravlja območni razvojni program.

Medtem ko za izdelavo obeh omenjenih prostorskih dokumentov obstaja metodika, ki je opredeljena $\mathrm{v}$ podzakonskih aktih (Pravilnik), in se za pripravo območnega razvojnega programa smiselno uporabljajo določbe iz Navodila, za občinske razvojne strategije ne obstaja enotno predpisana metodologija.

$\mathrm{Na}$ lokalni ravni je v novem Zakonu o varstvu okolja predvidena priprava lokalnih programov varstva okolja za mestne občine. Takšne programe lahko pripravijo tudi ostale, nemestne občine. Pri pripravi programov se smiselno uporabljajo zakonska določila, ki se nanašajo na pripravo nacionalnega programa varstva okolja, Resolucija pa predvideva tudi oblikovanje ustreznih navodil. 


\subsection{Skupne ugotovitve}

V poglavju sintezno predstavljamo sistem razvojnega, prostorskega in okoljskega načrtovanja po teritorialnih ravneh ter opozarjamo na nekatere strukturne pomanjkljivosti, ki se leto in pol pred koncem sedanjega programskega obdobja (2001-2006) kažejo pri izvajanju načrtovanja.

Državna raven

\begin{tabular}{|l|l|l|}
\hline \multicolumn{1}{|c|}{$\begin{array}{c}\text { OBSTOJEČI DOKUMENTI } \\
\text { RAZVOJNEGA NAČRTOVANJA }\end{array}$} & \multicolumn{1}{|c|}{ STATUS DOKUMENTA } & \multicolumn{1}{c|}{$\begin{array}{c}\text { VKLJUČENOST PROSTORSKEGA IN } \\
\text { OKOLJSKEGA VIDIKA }\end{array}$} \\
\hline $\begin{array}{l}\text { Strategija gospodarskega razvoja Slovenije } \\
2001-2006 \text { (SGRS) }\end{array}$ & $\begin{array}{l}\text { Veljaven temeljni državni strateški } \\
\text { dokument, osnova za pripravo DRP. }\end{array}$ & $\begin{array}{l}\text { Usmeritev regionalnega in prostorsko } \\
\text { skladnega razvoja je eden od petih } \\
\text { mehanizmov za dosego ciljev SGRS. }\end{array}$ \\
\hline $\begin{array}{l}\text { Državni razvojni program 2001-2006 } \\
\text { (DRP) }\end{array}$ & $\begin{array}{l}\text { Uporabljen kot gradivo za pripravo EPD ter } \\
\text { usklajevanje z Evropsko komisijo in RRP. }\end{array}$ & $\begin{array}{l}\text { Zastopanost v programih dveh prednostnih } \\
\text { nalog. }\end{array}$ \\
\hline Enotni programski dokument (EPD) & $\begin{array}{l}\text { Veljaven izvedbeni dokument z } \\
\text { opredeljenimi razvojnimi nalogami, ki bodo } \\
\text { do leta 2006 sofinancirane iz evropskih } \\
\text { strukturnih skladov. }\end{array}$ & $\begin{array}{l}\text { Prostorskih in okoljskih vsebin praktično ni } \\
\text { zaslediti. }\end{array}$ \\
\hline
\end{tabular}

\begin{tabular}{|l|l|l|}
\hline $\begin{array}{l}\text { OBSTOJEČI DOKUMENTI REGIONALNE } \\
\text { STRUKTURNE POLITIKE }\end{array}$ & \multicolumn{1}{|c|}{ STATUS DOKUMENTA } & \multicolumn{1}{c|}{$\begin{array}{c}\text { VKLJUČENOST PROSTORSKEGA IN } \\
\text { OKOLJSKEGA VIDIKA }\end{array}$} \\
\hline $\begin{array}{l}\text { Strategija regionalnega razvoja Slovenije } \\
\text { (SRRS) }\end{array}$ & $\begin{array}{l}\text { Veljaven strateški dokument, ki pa v praksi } \\
\text { ni odigral te vloge. }\end{array}$ & $\begin{array}{l}\text { Vključenost prostorskega vidika prek } \\
\text { uresničevanja cilja ohranjanja minimalne } \\
\text { poseljenosti na celotnem ozemlju RS. }\end{array}$ \\
\hline
\end{tabular}

\begin{tabular}{|l|l|l|}
\hline $\begin{array}{c}\text { OBSTOJEČI DOKUMENTI } \\
\text { PROSTORSKEGA NAČRTOVANJA }\end{array}$ & \multicolumn{1}{|c|}{ STATUS DOKUMENTA } & \multicolumn{1}{c|}{$\begin{array}{c}\text { VKLJUČENOST PROSTORSKEGA IN } \\
\text { OKOLJSKEGA VIDIKA }\end{array}$} \\
\hline $\begin{array}{l}\text { Strategija prostorskega razvoja Slovenije } \\
\text { (SPRS) }\end{array}$ & $\begin{array}{l}\text { Veljaven temeljni državni strateški } \\
\text { dokument o usmerjanju razvoja v prostoru. }\end{array}$ & $\begin{array}{l}\text { Določa strateške usmeritve razvoja } \\
\text { dejavnosti v prostoru, okoljski vidik, vključen } \\
\text { v obliki posebnega cilja, in pri obravnavi } \\
\text { prostorskih sistemov. }\end{array}$ \\
\hline
\end{tabular}

\begin{tabular}{|l|l|l|}
\hline \multicolumn{1}{|c|}{$\begin{array}{c}\text { OBSTOJEČI DOKUMENTI } \\
\text { OKOLJSKEGA NAČRTOVANJA }\end{array}$} & \multicolumn{1}{|c|}{ STATUS DOKUMENTA } & \multicolumn{1}{c|}{$\begin{array}{c}\text { VKLJUČENOST PROSTORSKEGA IN } \\
\text { OKOLJSKEGA VIDIKA }\end{array}$} \\
\hline $\begin{array}{l}\text { Resolucija o nacionalnem programu } \\
\text { varstva okolja (Resolucija) }\end{array}$ & $\begin{array}{l}\text { Veljaven državni strateško-programski } \\
\text { dokument na področju varstva okolja } \\
\text { (sledi še izdelava operativnih programov). }\end{array}$ & $\begin{array}{l}\text { Določa načela in strateške usmeritve ter } \\
\text { cilje, programe ukrepov, akterje, } \\
\text { mednarodne aktivnosti, financiranje na } \\
\text { področju varstva okolja. }\end{array}$ \\
\hline
\end{tabular}

Regionalna raven

\begin{tabular}{|l|l|l|}
\hline $\begin{array}{c}\text { OBSTOJEČI DOKUMENTI } \\
\text { REGIONALNE STRUKTURNE POLITIKE }\end{array}$ & \multicolumn{1}{|c|}{ STATUS DOKUMENTA } & \multicolumn{1}{c|}{$\begin{array}{c}\text { VKLJUČENOST PROSTORSKEGA IN } \\
\text { OKOLJSKEGA VIDIKA }\end{array}$} \\
\hline Regionalni razvojni programi (RRP) & $\begin{array}{l}\text { Obvezni dokumenti - obstoj 12 veljavnih } \\
\text { RRP na ravni statističnih regij. }\end{array}$ & $\begin{array}{l}\text { Enakovredna vključenost ob gospodarskem } \\
\text { in socialnem vidiku. }\end{array}$ \\
\hline
\end{tabular}

\begin{tabular}{|l|c|c|}
\hline \multicolumn{1}{|c|}{$\begin{array}{c}\text { OBSTOJEČI DOKUMENTI } \\
\text { PROSTORSKEGA NAČRTOVANJA }\end{array}$} & \multicolumn{1}{|c|}{ STATUS DOKUMENTA } & \multicolumn{1}{c|}{$\begin{array}{c}\text { VKLJČENOST PROSTORSKEGA IN } \\
\text { OKOLJSKEGA VIDIKA }\end{array}$} \\
\hline $\begin{array}{l}\text { Regionalna zasnova prostorskega razvoja } \\
\text { (RZPR) }\end{array}$ & $\begin{array}{l}\text { Dogovorni partnerski dokument }-v \text { pripravi } \\
\text { je 5 RZPR, vendar dokument ni bil sprejet } \\
\text { še v nobeni od } 12 \text { statističnih regij. }\end{array}$ & $\begin{array}{l}\text { Določa zasnove prostorskih ureditev, } \\
\text { usklajenih z državo in občinami, okoljski } \\
\text { vidiki vključeni neposredno ali posredno. }\end{array}$ \\
\hline
\end{tabular}

\begin{tabular}{|l|l|l|}
\hline $\begin{array}{c}\text { OBSTOJEČI DOKUMENTI NAČRTOVANJA } \\
\text { NA PODROČJU OKOLJA }\end{array}$ & \multicolumn{1}{|c|}{ STATUS DOKUMENTA } & \multicolumn{1}{c|}{$\begin{array}{c}\text { VKLJUČENOST PROSTORSKEGA IN } \\
\text { OKOLJSKEGA VIDIKA }\end{array}$} \\
\hline Regionalni programi varstva okolja & $\begin{array}{l}\text { Pripravo dokumenta dopušča novi Zakon } \\
\text { o varstvu okolja - po naših informacijah } \\
\text { obstaja vsaj en takšen dokument. }\end{array}$ & $\begin{array}{l}\text { Obravnava okoljskih vidikov na regionalni } \\
\text { ravni. }\end{array}$ \\
\hline
\end{tabular}


Lokalna raven

\begin{tabular}{|l|l|l|}
\hline $\begin{array}{c}\text { OBSTOJEČI DOKUMENTI } \\
\text { REGIONALNE STRUKTURNE POLITIKE }\end{array}$ & \multicolumn{1}{|c|}{ STATUS DOKUMENTA } & \multicolumn{1}{|c|}{$\begin{array}{c}\text { VKLJUČENOST PROSTORSKEGA IN } \\
\text { OKOLJSKEGA VIDIKA }\end{array}$} \\
\hline Območni razvojni programi (ORP) & $\begin{array}{l}\text { Možen dokument, ki nastane na pobudo } \\
\text { območnega razvojnega partnerstva - } \\
\text { 1 pripravljen in 1 v pripravi. }\end{array}$ & $\begin{array}{l}\text { Enakovredna vključenost ob gospodarskem } \\
\text { in socialnem vidiku. }\end{array}$ \\
\hline Občinski razvojni programi & $\begin{array}{l}\text { Ni obvezen dokument, je le sestavina } \\
\text { občinskega proračuna. }\end{array}$ & $\begin{array}{l}\text { Enovita metodika ne obstaja, zato je } \\
\text { vključenost prostorskega in okoljskega } \\
\text { vidika od primera do primera različna. }\end{array}$ \\
\hline
\end{tabular}

\begin{tabular}{|l|l|l|}
\hline \multicolumn{1}{|c|}{$\begin{array}{c}\text { OBSTOJEČI DOKUMENTI } \\
\text { PROSTORSKEGA NAČRTOVANJA }\end{array}$} & \multicolumn{1}{|c|}{ STATUS DOKUMENTA } & \multicolumn{1}{c|}{$\begin{array}{c}\text { VKLJUČENOST PROSTORSKEGA IN } \\
\text { OKOLJSKEGA VIDIKA }\end{array}$} \\
\hline $\begin{array}{l}\text { "Območna« regionalna zasnova } \\
\text { prostorskega razvoja (ORZPR) }\end{array}$ & $\begin{array}{l}\text { Dogovorni partnerski dokument, ki se } \\
\text { lahko pripravi predvsem v povezavi z } \\
\text { ORP - do sedaj ni bila pripravljena še } \\
\text { nobena ORZPR. }\end{array}$ & $\begin{array}{l}\text { Določa zasnove prostorskih ureditev, usklaje- } \\
\text { nih med državo in občinami. }\end{array}$ \\
\hline $\begin{array}{l}\text { Strategija prostorskega razvoja občine } \\
\text { (SPRO) }\end{array}$ & $\begin{array}{l}\text { Obvezen dokument - občine začenjajo } \\
\text { z njegovo pripravo. }\end{array}$ & $\begin{array}{l}\text { Določa usmeritve za razvoj dejavnosti v } \\
\text { prostoru in njegove rabe, da so zagotovljene } \\
\text { razmere za vzdržen in usklajen razvoj na } \\
\text { območju občine. }\end{array}$ \\
\hline
\end{tabular}

\begin{tabular}{|l|l|l|}
\hline \multicolumn{1}{|c|}{ OBSTOJEČI DOKUMENTI } \\
NAČRTOVANJA NA PODROČJU OKOLJA
\end{tabular}

\section{Usmeritve}

\section{za vključevanje prostorskega in okoljskega vidika $\mathrm{v}$ novo generacijo regionalnih razvojnih programov (2007-2013)}

Predlogi usmeritev za vključevanje prostorskega in okoljskega vidika $\mathrm{V}$ novo generacijo RRP temeljijo na preseganju ugotovljenih neskladij med vodenjem regionalne strukturne politike in urejanjem prostora ter varstvom okolja.

\section{1 Širše sistemske usmeritve}

$\mathrm{V}$ sedanjem sistemu razvojnega in prostorskikega načrtovanja se kažejo pomanjkljivosti, ki bi jih bilo smo- trno odpraviti. $V$ ta namen bi bilo potrebno:

- razločiti in upoštevati različne časovne okvire za vodenje razvojnega načrtovanja in regionalne strukturne politike, ki sta po svojem značaju in vpetosti v programska obdobja srednjeročnega značaja (5-7 let), ter za vodenje prostorskega načrtovanja, ki je po paradigmi in tradiciji dolgoročnega značaja (15-20 let). To razločevanje mora biti upoštevano pri pripravi celotne strukture dokumentov (državna, regionalna in lokalna raven);

- dopolniti zdajšnje ali pripraviti nove zakonske podlage, ki bodo zagotovile obvezno pripravo medsebojno primerljivih in povezljivih strateških in izvedbenih dokumentov za vodenje razvojnega načrtovanja in regionalne strukturne politike ter prostorskega načrtovanja na državni, regionalni in lokalni ravni;

- kar zadeva varstvo okolja na regionalni ravni, sprožiti čim širšo razpravo o tem, ali je ob ustrez- nem načinu vključevanja okoljskih vsebin v RZPR in RRP smotrna priprava regionalnih programov varstva okolja ali regionalnih strategij trajnostnega razvoja. $\mathrm{V}$ skladu $\mathrm{z}$ rezultati razprave bi bilo potrebno natančneje opredeliti načine vključevanja okoljevarstvenih vsebin in trajnostnega razvoja $\mathrm{v}$ oba tipa dokumentov in/ali začeti spodbujati pripravo regionalnih programov varstva okolja in trajnostnega razvoja;

- pripraviti in sprejeti zakonske podlage za to, da bodo resorna ministrstva pri strateškem načrtovanju in izvajanju svojih nalog upoštevala temeljne strateške in izvedbene dokumente na državni (SGRS, SRS, DRP) in regionalni ravni (RRP, RZPR);

- pripraviti in sprejeti zakonske podlage za teritorializacijo sektorskih strateških razvojnih dokumentov na ravni statističnih regij;

- pripraviti in sprejeti zakonske podlage za vzpostavitev regionalnih državnih izpostav oz. vladnih uradov na regionalni 
ravni, ki bi skrbeli za poenoteno usmerjanje in izvajanje državnih razvojnih politik;

- pripraviti in sprejeti zakonske podlage za okrepitev usmerjevalne vloge Sveta za strukturje odgovoren za usklajenost predlogov dokumentov za izvajanje regionalne strukturne politike na državni ravni;

- pripraviti in sprejeti zakonske podlage za okrepitev vloge organa na ravni regije odgovornega za vsebinsko usmerjanje in spremljanje priprave, sprejemanja in izvajanja RRP;

- pripraviti in sprejeti zakonske podlage za enakovredno vključenost vseh razvojnih deležnikov in širše javnosti $v$ vseh fazah priprave, sprejemanja in izvajanja razvojnih dokumentov.

\subsection{Usmeritve, vezane na pripravo RRP}

V načrtu priprave DRP 2007-2013 [19] je predstavljen sistem povezovanja dokumentov razvojnega načrtovanja, ki naj bi nastali kot rezultat interdisciplinarnega in medsektorskega procesa razvojnega načrtovanja. Obenem je izpostavljena potreba po opredelitvi transparentnih postopkov in nosilcev priprave razvojnih dokumentov (glej diagram 1). no politiko kot organa vlade, ki

Pomembno izhodišče omenjenega načrta je zahteva po pripravi 12 RZPR, ki naj bi bili enako kot RRP pripravljene za 12 statističnih regij. $\mathrm{S}$ tem je država posredno izrazila odločenost ustvariti (zakonske) pogoje, na osnovi katerih bi bila obvezna priprava RZPR na teritorialni ravni, na kateri bo potekala tudi priprava nove generacije RRP.

Obvezna priprava RZPR kot dolgoročnega strateškega prostorskega dokumenta na regionalni ravni oz. za 12 statističnih regij bi zapolnila prostorsko in razvojno načrtovalsko vrzel, ki je - s pretežno problemsko usmerjeno, dogovorno in teritorialno neobvezujočo obliko in vsebino RZPR - nastala med obvezno pripravo Strategije prostorskega razvoja Slovenije in strategij prostorskega razvoja občin. Tako bi se ponovno vzpostavila celovita in medsebojno povezana struktura strateških prostorskih dokumentov na državni, regionalni in lokalni ravni.

Podobno hierarhijo dokumentov bi bilo potrebno vzpostaviti tudi na področju priprave in izvajanja dokumentov razvojnega načrtovanja oz. vodenja regionalne strukturne politike. Tukaj je potrebno odpraviti načrtovalsko vrzel, ki nastaja zaradi umanjkanja celovitega in metodično poenotenega razvojnega dokumenta na lokalni ravni - občinskega razvojnega programa.

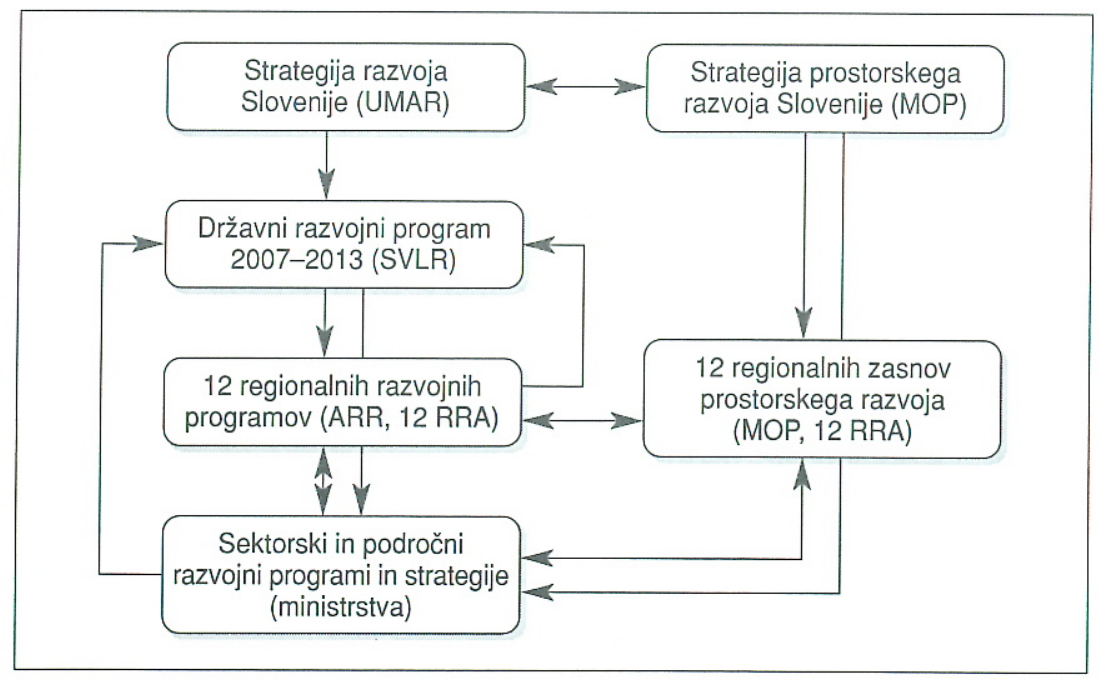

Diagram 1: Povezave postopkov in nosilcev priprave razvojnih dokumentov
Če bi se vzpostavila celovita struktura medsebojno povezanih razvojnih dokumentov na področju razvojnega načrtovanja oz. vodenja regionalne strukturne politike ter prostorskega načrtovanja, bi lahko območni razvojni programi in »območne« regionalne zasnove prostorskega razvoja zadržali svoj sedanji opcijski značaj.

Kljub temu da do sedaj še ni bil sprejet noben celovit RZPR - v fazi priprave predloga so RZPR za koroško in savinjsko regijo ter regijo jugovzhodna Slovenija - so izkušnje pokazale, da je metodika njihove priprave, kot jo določa Pravilnik, ustrezna in bi jo veljalo ohraniti tudi pri pripravi RZPR v preostalih statističnih regijah.

Metodika priprave RZPR vsebuje vse potrebne analitične (problemska analiza stanja) in programske osnove (cilji, usmeritve, scenariji, vizija, zasnove prostorskih sistemov, usmeritve za pripravo državnih in medobčinskih lokacijskih načrtov in krajinskih zasnov, program ukrepov za izvajanje regionalne zasnove vključno s kazalniki spremljanja) dolgoročnega značaja, ki se lahko uporabijo kot ključna osnova za pripravo strateškega dela RRP za področje prostora in deloma okolja.[20]

Pri opredeljevanju razvojnih prioritet, programov in podprogramov na področju prostora in okolja je potrebno ob upoštevanju vsebine razvojnih prioritet, programov in podprogramov na področjih gospodarskega in socialnega razvoja vzpostaviti sistem izbora tistih vsebin, ki bi bile najbolj potrebne oz. primerne za izvedbo $\mathrm{v}$ aktualnem programskem obdobju. Poglobljenost obravnave prostorskih in okoljskih vsebin vse do ravni projektov $v$ RZPR omogoča skoraj neposredno vključitev v strateški in izvedbeni del RRP.

Ključnega pomena pri prenosu prostorskih in okoljskih vsebin iz RZPR v RRP sta vzpostavitev in de- 


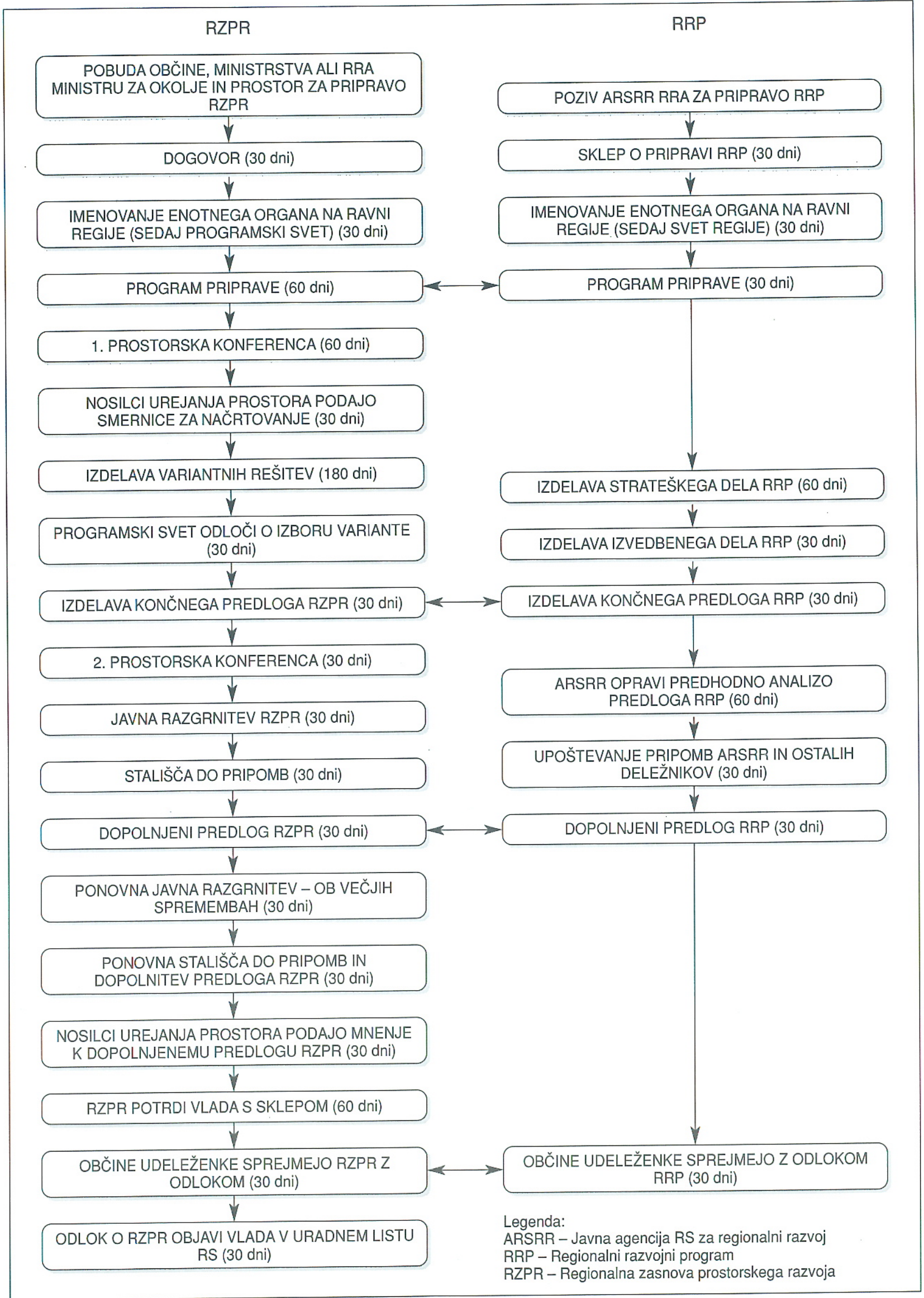

Diagram 2: Postopek priprave in sprejema regionalne zasnove prostorskega razvoja in regionalnega razvojnega programa 
lovanje enotnega organa na ravni regije, odgovornega za vsebinsko usmerjanje in spremljanje priprave ter izvajanja RRP in RZPR. To bi pomenilo združitev sestave in funkcij programskega sveta, ki usmerja pripravo RZPR, in sveta regije, ki usmerja pripravo RRP, $v$ enoten organ na ravni regije. Ta bi skrbel za usmerjanje, spremljanje in vrednotenje vseh dejavnosti razvojnega načrtovanja, vodenja regionalne strukturne politike ter prostorskega načrtovanja na ravni statističnih regij. Poleg tega bi bilo potrebno vzpostaviti zakonske osnove $\mathrm{za}-$ kot smo zapisali v opredelitvi širših sistemskih usmeritev - enakovredno vključevanje vseh razvojnih deležnikov in širše javnosti v vse faze priprave, sprejemanja in izvajanja razvojnih dokumentov.

Kar zadeva okoljski vidik v RRP, je v primerih, ko so bili pripravljeni regionalni okoljski programi, smotrn tudi prevzem teh vsebin. Ne glede na postopek priprave regionalnih okoljskih programov se okoljske vsebine pri pripravi RRP v vseh fazah preverjajo in po potrebi dopolnjujejo. Razmisliti velja tudi o sprotni strateški presoji vplivov načrtovanih aktivnosti na drugih področjih RRP, predvsem gospodarskem, na okolje.

Na koncu bi želeli opozoriti, da je zaradi različne časovne zahtevnosti priprave RZPZ in RRP - zaradi zelo zahtevnega postopka traja priprava RZPR do formalnega sprejema dokumenta približno 20 mesecev, priprava RRP pa približno 10 mesecev - zelo otežena ali skoraj neizvedljiva sočasna priprava in sprejemanje obeh dokumentov. ${ }^{[21]}$ Iz tega sledi, da je pripravo RZPR treba začeti prej. Če bi želeli hkrati končati pripravo in sprejemanje obeh dokumentov v regijah, bi se priprava RRP lahko začela v času razgrnitve RZPR.

Mag. Andrej Gulič, univ. dipl. soc.; Sergeja Praper, univ. dipl. inž. kmet. Urbanistični inštitut RS, Ljubljana

E-pošta: andrej.gulic@urbinstitut.si, sergeja.praper@urbinstitut.si
Opombe

[1] Članek temelji na prispevkih avtorjev za projekt Strokovne podlage za pripravo nove generacije regionalnih razvojnih programov za programsko obdobje 2007-2013, ki ga izvaja Center za mednarodno konkurenčnost $v$ sodelovanju z Inštitutom za ekonomska raziskovanja in Urbanističnim inštitutom RS.

[2] Ur. I. RS, št. 52/2000, 111/2000, 44/2001, 110/2004, 39/2005.

[3] Ur. I. RS, št. 60/1999, 56/2003.

[4] Ravbar, M., Gulič, A., Kavaš, D. et al., 2004, Spremljanje regionalnega razvoja, Geografski inštitut Antona Melika ZRC SAZU, Urbanistični inštitut RS, Inštitut za ekonomska raziskovanja, naročnika Ministrstvo za šolstvo, znanost in šport ter Javna agencija RS za regionalni razvoj, Ljubljana.

[5] http://www.alppeca.si/prrp/ RRPkoroska.pdf

[6] http://rzpr-koroska.urbinstitut.si/

[7] http://rzpr-savinjska.urbinstitut.si/

[8] http://www.uradni-list.si/1/objava. jsp?urlid=2002110\&stevilka $=5386$

[9] http://www.gov.si/upr/doc/sprs/ SPRS260104/SPRS_260104_celota.pdf

[10] Ur. I. RS, št. 41/04.

[11] Resolucija je bila sprejeta 2. junija 2005, operativni programi pa so še v pripravi.

[12] http://www.gov.si/arr/9razno/1dr3.html

[13] http://www.gov.si/svrp/3str/pdf/epd/ enotni_programski_dokument_rs_ 2004-2006.pdf

[14] http://www.gov.si/euskladi/skladi/ kohezija.html

[15] http://www.gov.si/euskladi/skladi/ kohezija.html

[16] http://www.uradni-list.si/1/objava. jsp?urlid =200424\&stevilka $=1063$

[17] http://www.ra-sora.si/upload/orp.pdf

[18] http://obcina.kranjska-gora.si/ predpisi/razvojni\%20program.pdf, http://www.litija.net/rcl/kazalo.htm, http://rogaska.onair.si/katalog/ dokumenti/irpors_03_06.pdf

[19] Dopolnjena različica z dne 9. aprila 2005

[20] V RZPR za koroško in savinjsko regijo je bila pripravljena zasnova varstva okolja po tipih območij, obravnavan pa je tudi organizacijski vidik varstva okolja. Tipi območij zajemajo npr. strnjena naselja, območja razpršene poselitve, gospodarske cone in industrijska območja, območja ob obremenjenih prometnicah, območja intenzivne kmetijske proizvodnje, območja s poškodovanim gozdom in okoljsko večplastno degradirana območja.

[21] V diagramu 2 sta predstavljena postopka priprave RZPR in RRP, kot izhajata iz sedaj veljavnih podzakonskih aktov, ter po mnenju avtorjev besedila zaželene točke njunega vsebinskega povezovanja. 